\title{
METODE "KLP” DALAM PEMBELAJARAN MATA KULIAH ILMU-ILMU KEISLAMAN DI PTKIN/S
}

\author{
Elmansyah \\ IAIN Pontianak, Indonesia \\ elmans@iainptk.ac.id
}

\begin{abstract}
The Kuliah Langsung-Presentasi (Direct Learning-Presentation/KLP) method is a learning method designed to address the problem of student inactive in learning with a classroom seminar model. This method is believed to increase reading, writing and thinking sklill to express students' ideas of learning. This method was developed based on the results of research conducted through Classroom Action Research, from 2017-2018 in State Islamic/Private Islamic University (PTKI N/S) in West Kalimantan. Data collection was done by Interview Technique, Learning Practice Test and Questionnaire. The data analysis used Likert Scale model. The results obtained of this study are that there are significant influences and significant differences on the use of KLP's on student learning outcomes in the course of Islamic Sciences in PTKIN/S.
\end{abstract}

Keywords: Learning Method, KLP and Islamic Sciences.

\begin{abstract}
Abstrak: The Direct Perform-Method (KLP) adalah sebuah metode pembelajaran yang didesain untuk mengatasi problem kekurang-aktifan mahasiswa dalam pembelajaran dengan model seminar kelas. Metode ini diyakini mampu meningkatkan daya baca, daya tulis dan daya berfikir mahasiswa. Metode ini dikembangkan berdasarkan hasil penelitian yang dilakukan melalui Penelitian Tindakan Kelas (Classroom Action Research), sejak tahun 2017-2018 di Perguruan Tinggi Keagamaan Islam Negeri/Swasta (PTKIN/S) di Wilayah Kalimantan Barat. Pengumpulan data dilakukan dengan teknik wawancara, Uji Praktek Pembelajaran dan Kuesioner. Analisis data menggunakan model Skala Likert. Hasil yang diperoleh dalam penelitian ini adalah bahwa ada pengaruh dan perbedaan signifikan atas penggunaan DPM terhadap hasil belajar mahasiswa pada mata kuliah Ilmu-ilmu keislaman di PTKIN/S.
\end{abstract}

Kata Kunci: Metode Pembelajaran, KLP dan Ilmu-ilmu Keislaman.

\section{A. Pendahuluan}

"KLP" adalah akronim dari bahasa Indonesia, yang awalnya berupa singkatan dari kutipan langsung atau tak Langsung, kemudian presentasi. Berdasarkan praktek di lapangan, KLP bisa juga diterjemahkan ke dalam bahasa Inggris dengan akronim yang bermacam-macam pada seputar pembelajaran aktif: Knowing Learning Procedures (Mengetahui Prosedur-prosedur Pembelajaran), Keys to Learn Presentation (Kunci-kunci untuk belajar presentasi), Keys to Learn and Process (Kunci-kunci untuk belajar dan Proses Belajar), Keeping of Literature Paper (Memelihara/menjaga Karya Ilmiah Kepustakaan), Keynote of Library Project (Pokok-pokok Proyek Pustaka), Key 
Leads Presentation (Kunci Menuju Presentasi yang baik), dan Keynote of Learning Product (Kunci Memahami Produk)1.

Metode ini lahir dari melihat berbagai fenomena belajar mahasiswa di beberapa perguruan tinggi, baik negeri maupun swasta di Kalimantan Barat yang cenderung lebih mengandalkan literatur internet dari pada literatur buku manual². Kecenderungan itu, awalnya masih bersifat positif, namun lama kelamaan mulai negatif, dengan maraknya aksi plagiarisme dalam penyelesaian tugas mata kuliah ilmu-ilmu keislaman, seperti: Akhlak Tasawuf, Ilmu Kalam, Metodologi Studi Islam, dan Pendidikan Agama Islam pada Perguruan Tinggi Umum (PTU).

Fenomena belajar mahasiswa tergambar dalam suatu aktifitas pembelajaran di kelas yang selalu saja hampir sama. Empat mahasiswa maju ke depan kelas. Mahasiswa pertama mengantarkan prolog dengan memperkenalkan materi dan teman-temannya. Mahasiswa kedua membacakan kalimat-kalimat yang tertayang di Slide Powerpoint. Mahasiswa Ketiga sibuk dengan gadget kesayangannya, sedangkan Mahasiswa Keempat siap dengan kertas selembar untuk menulis. Lengkaplah mereka berempat dengan tema "Presentasi Materi Kuliah". Sekilas, memang tidak nampak ada kejanggalan dalam gambaran presentasi materi mahasiswa di atas, tapi mari kita lebih jauh. Mulai dari slide yang ditayangkan, umumnya slide itu tidak berupa pointer, melainkan kalimat-kalimat utuh yang membentuk paragraf. Presenter membacakan kalimat-kalimat itu dengan tanpa interpretasi. Setelah selesai dibacakan, dibukalah kesempatan untuk bertanya.

Di sinilah puncaknya, setiap kali menjawab pertanyaan, mereka langsung tertuju pada mahasiswa yang mengendalikan gadget. Butuh waktu cukup lama untuk menjawab. Usut punya usut, ternyata mereka mengandalkan google search untuk mencari jawaban. Belum lagi jika melihat makalah yang dikumpulkan. Dengan alasan kesulitan mencari buku referensi, mereka menggunakan jasa blog

1 Elmansyah, Studi Eksperimentasi Metode KLP dalam Pembelajaran Mata Kuliah Ilmu-ilmu Keislaman di IAIN Pontianak dan STAI Mempawah Tahun 2017, Naskah Laporan Penelitian Kompetitif Individual, Pontianak: LP2M IAIN Pontianak, 2017, hlm. 5.

2 Hal ini terlihat dari hasil pengamatan lapangan selama penulis menjadi mengajar di beberapa perguruan tinggi di Kalimantan Barat (Universitas Muhammadiyah Pontianak, IAIN Pontianak, Sekolah Tinggi Agama Islam Mempawah (STAIM), Poltekkes Kemenkes Pontianak, dan STAISA Walisongo Pontianak (sekarang sudah ditiadakan). Hampir semua tugas makalah mahasiswa diambil dari internet, baik dari blog maupun website. 
untuk di-copy-paste. Lebih parahnya lagi, copy-paste itu tidak diiringi dengan editing yang maksimal, sehingga hasilnya sungguh memprihatinkan. ${ }^{3}$

Barangkali ini semua merupakan salah satu pengaruh negatif teknologi informasi yang berkembang demikian pesat saat ini, sehingga membutuhkan penanganan yang serius dalam bidang pembelajaran. Hal ini diakui oleh Endang Supriyati dari Fakultas Teknik Informatika Universitas Muri Kudus, dari hasil penelitiannya bahwa teknologi informasi yang berkembang sangat pesat, masih belum digunakan secara bijak dalam meningkatkan pemahaman atas materi perkuliahan. Ada beberapa model pemanfaatan teknologi informasi yang digunakan oleh berbagai lembaga pendidikan, misalnya: Unduh Materi Via Blog/Wordpress, Grup Diskusi di facebook, Video Tutorial, Download Jurnal Online, dan Download ebook ${ }^{4}$. Peningkatan pemahaman perkuliahan justru diperoleh dari Blog/Wordpress. Barangkali itulah sebabnya, mahasiswa cenderung mencari materi di Blog/Wordpress. Masalahnya kemudian, materi tersebut ketika diminta untuk membuat makalah, hanya diunduh lalu dicopy dan langsung diserahkan tanpa dipelajari dengan seksama ${ }^{5}$.

Meminjam istilah Djamaluddin, "perlunya reorientasi" dalam pembelajaran mata kuliah ilmu-ilmu keislaman, mengingat tantangan globalisasi yang luar biasa mempengaruhi generasi muda ${ }^{6}$. Banyak yang menawarkan solusi, seperti: Ketut Nurhayanti ${ }^{7}$, Eri Achiraeniwati, dkk. ${ }^{8}$, Aldarmono ${ }^{9}$, dan lain sebagainya. Masing-

${ }^{3}$ Elmansyah, Memerangi Plagiarisme di Kalangan Mahasiswa, Harian Pontianak Post, 28 Januari 2014, hlm. 7.

${ }^{4}$ Endang Supriati, "Strategi Pembelajaran Berbasis Teknologi Informasi", dalam SUMETRIS: Jurnal Teknik Mesin, Elektro dan Ilmu Komputer, Vol. 2, No. 1, 2013.

${ }^{5}$ Elmansyah, Memerangi Plagiarisme..., hlm. 7.

${ }^{6}$ Djamaluddin, "Reorientasi Pembelajaran Akhlak Tasawuf di Perguruan Tinggi", dalam Tadris: Jurnal Pendidikan Islam, Vol. 3, No. 1, 2008.

7 Ketut Nurhayanti, Dosen Politeknik Negeri Bali, menawarkan solusi melalui penggunaan staregi pembelajaran berbasis masalah. Berdasarkan hasil penelitiannya, penggunaan isu masalah perspektif ganda merupakan hal terpenting sebagai materi ajar, khususnya mata kuliah Agama Hindu. Ketut Nurhayanti, "Penerapan Model Pembelajaran Isu Sosial-Keagamaan Berbasis Masalah Sebagai Strategi Mengajar Agama Hindu di Perguruan Tinggi", dalam Soshum: Jurnal Sosial dan Humaniora [Journal of Social Sciences and Humanities], [S.1.], Vol. 7, No. 1, September 2017.

8 Menurut Eri, dkk. Rancangan Kusi Kuliah yang sesuai dengan ukuran tubuh dan keinginan mahasiswa, dapat meningkatkan kenyamanan dan mendukung proses pembelajaran. Eri Achiraeniwati, Yanti Sri Rejeki, Nur Rahman As'ad, dan Widi Pratama, "Perancangan Ulang Kursi 
masing menawarkan model pembelajaran yang berbeda, namun pada intinya sama, yaitu model pembelajaran yang terpusat pada peserta didik. Akan tetapi, staregi khusus untuk mata kuliah ilmu-ilmu keislaman belum ditemukan.

Untuk mengatasi persoalan ini, penulis mencoba menerapkan model perkuliahan seminar kelas dengan metode KLP. Langkah-langkah yang ditempuh antara lain: membuat silabus yang dilengkapi dengan point-point materi, pada perkuliahan awal, mahasiswa dijelaskan tentang aturan main perkuliahan secara detail, mahasiswa ditugaskan untuk mencari materi dengan cara membuat kutipan langsung atau tidak langsung, berdasarkan point-point materi yang telah disiapkan sebelumnya (minimal lima kutipan literatur terbaru untuk setiap point), kutipan ditulis tangan di atas kertas folio bergaris, dikumpulkan sebagai tiket masuk untuk setiap individu sebelum perkuliahan dimulai, mahasiswa ditugaskan untuk presentasi hasil penelusuran materi secara dadakan (langsung presentasi); dan dosen menilai performa mahasiswa yang presentasi dan yang mengikuti perkuliahan.

Melalui model perkuliahan semacam ini, penulis merasakan adanya peningkatan yang signifikan dalam setiap materi kuliah yang diajarkan dalam seminar kelas. Berdasarkan hasil penelitian penulis tahun 2017, diperoleh data bahwa metode ini membawa dampak positif bagi peningkatan hasil belajar mahasiswa. Ada perbedaan signifikan antara sebelum dengan sesudah penggunaan metode KLP dalam pembelajaran mata kuliah dasar ilmu-ilmu keislaman (Akhlak Tasawuf, Ilmu Kalam dan Metologi Studi Islam) terhadap hasil belajar mahasiswa, di mana nilai rata-rata pada siklus I (sebelum) yaitu 71,98 dan meningkat pada siklus II (sesudah) menjadi 77,90. Selisih 5,92 point, yang menandakan adanya peningkatan signifikan atas perlakuan dengan menggunakan metode KLP dibandingkan dengan tidak menggunakan metode tersebut ${ }^{10}$.

Kuliah yang Ergonomis di Universitas Islam Bandung Jl. Tamansari Nomor 1 Bandung", dalam Ethos: Jurnal Penelitian dan Pengabdian, Vol. 6, No. 1, Januari 2018.

${ }_{9}^{9}$ Aldarmono menawarkan cara mengidentifikasi Gaya Kognitif Peserta Didik terlebih dahulu dalam belajar, agar pendidik dapat lebih mudah melaksanakan pembelajaran. Aldarmono, "Identifikasi Gaya Kognitif (Cognitive Style) Peserta Didik dalam Belajar", dalam Al-Mabsut: Jurnal Studi Islam dan Sosial, Vol. 3, No. 1, 2012.

${ }^{10}$ Elmansyah, Studi Eksperimentasi....., hlm. 78. 
Berdasarkan uraian di atas, jelas bahwa metode KLP menarik untuk dikembangkan di berbagai perguruan tinggi lain di Indonesia. Oleh karena itu, melalui artikel ini, penulis ingin menguraikan secara lebih komprehensif mengenai metode KLP bagi pembelajaran mata kuliah ilmu-ilmu keislaman.

\section{B. Metode Penelitian}

Penelitian ini merupakan penelitian eksperimen pembelajaran. Oleh karena itu, metode penelitian yang digunakan adalah metode penelitian Classroom Action Research atau Penelitian Tindakan Kelas (PTK). Penelitian tindakan kelas adalah suatu penelitian yang dilakukan secara sistematis reflektif terhadap berbagai "aksi" atau tindakan yang dilakukan oleh seorang dosen/pelaku, mulai dari perencanaan sampai dengan penilaian terhadap tindakan nyata di dalam kelas yang berupa kegiatan belajar mengajar untuk memperbaiki kondisi pembelajaran yang dilakukan ${ }^{11}$. Desain penelitian ini menggunakan desain penelitian Classroom Action Research model Kurt Lewin ${ }^{12}$. Konsep PTK Kurt Lewin terdiri dari empat komponen, yaitu perencanaan (planning), tindakan (acting), pengamatan (observing), dan refleksi (reflecting).

Penelitian ini dilaksanakan di dua Perguruan Tinggi Keagamaan Islam (PTKI) Negeri/Swasta. Untuk PTKI Negeri dilaksanakan di Institut Agama Islam Negeri (IAIN) Pontianak, yang terletak di Jl. Letjend Soeprapto No. 19 Pontianak Kalimantan Barat. Sedangkan untuk PTKI Swasta di Sekolah Tinggi Agama Islam (STAI) Mempawah, yang beralamat di Jl. Gusti Sulung Lelanang No. 1 Mempawah Hilir, Kabupaten Mempawah, Kalimantan Barat.

Alasan mengapa penelitian dilakukan di kedua tempat tersebut di atas didasarkan pada tiga hal: Pertama, untuk PTKIN di Kalimantan Barat hanya satu, yaitu IAIN Pontianak, sehingga tidak ada pilihan lagi, terutama yang mengajarkan mata kuliah ilmu-ilmu keislaman, seperti Tasawuf, Ilmu Kalam dan Metodologi Studi Islam. Kedua, untuk PTKIS, STAI Mempawah cukup representatif bagi perguruan tinggi keagamaan Islam swasta di Kalimantan Barat, karena letaknya

11 Depdikbud, Penelitian Tindakan Kelas (Class Room Action Research), (Jakarta: Dikti Proyek, 1999), hlm. 120.

12 Ani Widayati, "Penelitian Tindakan Kelas", Jurnal Pendidikan Akuntansi Indonesia, Vol. VI, No. 1, 2008, hlm. 91. 
yang strategis dan mahasiswanya cukup banyak. Ketiga, karena keterbatasanketerbatasan peneliti dalam kaitannya dengan pembiayaan, waktu dan tenaga, sehingga penelitian ini hanya dilakukan di dua tempat tersebut.

Penelitian ini dilaksanakan selama delapan bulan, yaitu sejak bulan Maret 2017 s.d. bulan November 2017. Dengan demikian, penelitian ini melewati dua semester tahun akademik, yaitu tahun akademik 2016-2017 Genap dan tahun akademik 2017-2018 Ganjil. Untuk di IAIN Pontianak, penelitian dilakukan pada bulan Mei 2017, sedangkan STAI Mempawah dilaksanakan dua tahap, yaitu pada bulan Mei 2017 dan bulan Oktober 2017.

Populasi penelitian ini terdiri dari mahasiswa di dua PTKI, yaitu: IAIN Pontianak dan STAI Mempawah. Populasi mahasiswa yang diuji coba penerapan metode ini berjumlah 180 orang. Populasi ini terbagi atas enam rombongan belajar, yang masing-masing diampu oleh enam dosen yang berbeda, yaitu: Muh. Gitosaroso, M.Ag. (Akhlak Tasawuf) pada Kelas D Semester 1 Jurusan Pendidikan Agama Islam (FTIK IAIN Pontianak), Ach. Tijani, M.Fill (Metodologi Studi Islam) pada Kelas C Semester 2 Jurusan Ekonomi Islam (FSEI IAIN Pontianak), Dr. Sahri, MA (Ilmu Kalam) pada Kelas B Semester 2 Jurusan Bimbingan Konseling Islam (FUAD IAIN Pontianak), Nurul Fathanah, M.H.I. (Akhlak Tasawuf) pada Kelas A Semester 1 Prodi Pendidikan Agama Islam (Tarbiyah STAI Mempawah), Naberi, M.H. (Ilmu Kalam) pada Kelas B Semester 1 Prodi Ahwal al-Syahsiyah (Syari'ah STAI Mempawah); dan, Ismail, M.Pd.I. (Metodologi Studi Islam) pada Kelas A Semester 3 Prodi Pendidikan Agama Islam (Tarbiyah STAI Mempawah).

Variabel bebas dalam penelitian ini terdiri dari dua variabel, yaitu: Pertama, mahasiswa semester 1-3 yang mengambil mata kuliah dasar ilmu-ilmu keislaman (Akhlak Tasawuf, Ilmu Kalam dan Metodologi Studi Islam). Kedua, dosen Pengampu mata kuliah dasar ilmu-ilmu keislaman (Akhlak Tasawuf, Ilmu Kalam dan Metodologi Studi Islam). 


\section{B. Implementasi Metode KLP dalam Pembelajaran}

\section{Landasan Teori Metode KLP}

Pembelajaran merupakan proses interaksi manusiawi yang ditandai dengan adanya keseimbangan antara kedaulatan subjek didik dengan kewibawaan pendidik. Pembelajaran terjadi apabila subjek didik secara aktif berinteraksi dengan lingkungan belajar yang diatur oleh dosen. Dosen bertugas membelajarkan peserta didik agar dapat berkembang dengan maksimal. Membelajarkan di sini dalam arti mengkondisikan peserta didik agar belajar aktif, baik secara kognitif, afektif, maupun konatif. Melalui pembelajaran, akan terlatih dan terbentuk kompetensi, yaitu kemampuan peserta didik untuk melakukan sesuatu yang sifatnya positif yang pada akhirnya akan membentuk life skill sebagai bekal hidup dan penghidupannya ${ }^{13}$.

Belajar dan pembelajaran membutuhkan metode agar keduanya dapat berhasil maksimal. Metode menjadi penting dalam kerangka mempermudah dan mempercepat pembelajaran. Karenanya, banyak metode yang ditawarkan oleh para ahli pembelajaran, seperti: active learning, cooperative learning, quantum learning, dan lain sebagainya yang pada dasarnya mendukung metode active learning.

Metode KLP juga berorientasi pada metode active learning, dengan menggunakan model seminar kelas. Metode "Active Learning" sudah lama dikembangkan oleh para ahli. Sebagaimana diketahui bahwa gagasan tentang 'active learning', sudah ada sejak zaman Socrates dan ditekankan kembali oleh John Dewey, yang menyatakan bahwa pada dasarnya, belajar adalah suatu proses yang aktif. Dalam ajaran Konfusius (24 abad silam), ada pernyataan-pernyataan yang terkait dengan masalah ini, yaitu: apa yang saya dengar; saya lupa, apa yang saya lihat; saya ingat, apa yang lakukan; saya paham ${ }^{14}$.

13 Ali Muhtadi, "Model Pembelajaran "Active Learning" dengan Metode Kelompok untuk Meningkatkan Kualitas Proses Pembelajaran di Perguruan Tinggi", Prosiding Seminar UPI Bandung, 2009, hlm. 2.

14 M. L. Silberman, Active Learning: 101 Strategi Pembelajaran Aktif (terjemahan), (Bandung: Nuansa, 2006), dalam Ali Muhtadi, "Model Pembelajaran "Active Learning" dengan Metode Kelompok untuk Meningkatkan Kualitas Proses Pembelajaran di Perguruan Tinggi," Naskah Prosiding Seminar Internasional, PPs Universitas Pendidikan Bandung, 2009, hlm. 7. 
Beberapa metode yang telah dikembangkan oleh para ahli dalam upaya mewujudkan pembelajaran aktif hingga saat ini, antara lain: Quantum Teaching/Learning (diciptakan oleh Bobbi De Potter, dkk. Antara 1980-an - 1991 di Super Camp, California, Amerika Serikat), Contextual Teaching Learning/CTL (diusulkan oleh John Dewey sejak 1916: Learning by doing, yang kemudian mengalami berbagai perubagan nama, seperti: experiential learning/1970-an, applied learning/1980-an, school to work/1990-an, dan sejak tahun 2000-an, CTL mulai baku digunakan), Model Eliciting Activities/MEA (1970-an), Active Learning (Melvin L. Silberman), Cooperative Learning (Herbert Thelen, 1960-an), dan lain sebagainya.

Pada dasarnya semua metode yang dikembangkan merupakan metode yang disusun dengan tujuan agar pembelajaran dapat berjalan dengan baik, aktif, kreatif, menyenangkan dan terpusat pada peserta didik. Pembelajaran semacam ini diyakini mampu meningkatkan kemampuan peserta didik secara lebih baik dan lebih cepat. Para pendidik dituntut untuk memberikan porsi yang lebih banyak bagi keaktifan peserta didik dalam proses belajar. Secara bertahap, peserta didik diarahkan untuk mandiri, mulai dari prosentasi yang terendah di tingkat sekolah dasar hingga yang tertinggi di perguruan tinggi, berdasarkan asumsi kedewasaan peserta didik tersebut.

Khusus di perguruan tinggi, mahasiswa merupakan peserta didik dalam kategori dewasa. Sehingga, keaktifan dalam pembelajaran, bahkan secara mandiri, mutlak ditekankan. Mahasiswa dituntut untuk banyak belajar di luar apa yang disampaikan oleh dosen di kelas atau laboratorium. Hal ini dikarenakan, porsi pertemuan dengan dosen sangat rendah dan perkembangan materi pembelajaran yang sangat cepat. Karenanya mahasiswa harus banyak berfikir, membaca dan menulis. Lebih lanjut, mahasiswa juga ditekankan untuk lebih banyak melakukan observasi, berekspresi, mengembangkan estetika, etika, epistemologi, teknologi bahkan teologi.

Menurut Mahmud Dimyati, sebagaimana dikutip oleh Ali Muhtadi, bahwa pembelajaran pada mahasiswa di Indonesia cenderung kurang menonjolkan kemampuan dasarnya, yaitu membaca, menulis, dan memikir (3m). Selain itu, 
ternyata belum juga menonjolkan observasi (o), ekspresi, estetika, etika, epistemologi, teknologi dan teologi (3e2t) $)^{15}$.

Belakangan ini, banyak ditemui upaya untuk mengembangkan pembelajaran aktif pada mahasiswa dalam bentuk seminar kelas. Upaya ini dimaksudkan untuk menjawab persoalan yang dikemukakan oleh Ali Muhtadi, bahwa mahasiswa belum menunjukkan kemampuan dasarnya, yaitu membaca, menulis dan berfikir. Oleh karena itu, metode seminar kelas diyakini mampu memberikan porsi yang lebih pada mahasiswa untuk membaca, menulis dan berfikir. Sebab, pada inti kegiatannya mahasiswa harus membuat makalah (baik individu maupun kelompok), kemudian mempresentasikan makalah tersebut di dalam kelas.

Proses pembuatan makalah ini tentu saja membutuhkan waktu yang panjang, di mana mahasiswa harus membaca puluhan buku referensi untuk dapat menuliskannya. Selain itu, dibutuhkan metode dan langkah-langkah konkrit agar dapat tercipta makalah dan presentasi yang baik. Tanpa itu semua, kecil kemungkinan untuk dapat membuat makalah yang bisa dipertanggung-jawabkan.

Oleh karena itu, diperlukan upaya ekstra untuk membuat para mahasiswa membaca, berfikir dan menulis. Melalui metode ini, peneliti menyodorkan sebuah metode baru yang dapat meningkatkan aktifitas membaca, menulis dan berfikir mahasiswa, sekaligus mengurangi plagiarisme yang rawan di kalangan mahasiswa. Metode ini peneliti sebut sebagai "Metode KLP". KLP merupakan singkatan dari Kuliah, Langsung, Presentasi. Metode ini mendukung metode yang sudah ada, yaitu metode seminar kelas, yang banyak digunakan oleh para dosen dalam mengajar mata kuliah dasar ilmu-ilmu keislaman.

\section{Langkah-Langkah Implementasi Metode KLP}

Metode KLP adalah metode pembelajaran yang berbasis seminar kelas dan Riset sekaligus. Prinsip dasar metode ini adalah mahasiswa harus memiliki modal terlebih dahulu sebelum melakukan seminar kelas, sehingga seminar kelas akan bermakna sebagai pembelajaran lebih lanjut. Mahasiswa sebagai peserta didik dewasa, sudah sewajarnya belajar secara aktif dan mandiri.

${ }^{15}$ Muhtadi, Model Pembelajaran......, hlm. 6. 
Metode KLP mendukung metode 'Active Learning' dengan strategi seminar kelas yang dikembangkan dengan langkah-langkah tersendiri oleh dosen. Langkah-langkah yang ditempuh oleh dosen adalah sebagai berikut:

Pertama, dosen menyusun Rencana Perkuliahan Semester (RPS) sesuai dengan ketentuan struktur kurikulum yang telah ditetapkan oleh Program Studi masing-masing Perguruan Tinggi. RPS tersebut disusun dalam bentuk poin-poin beban kajian, di mana dalam satu materi pertemuan, dibuat 3-6 poin turunan dari pokok kajian, misalnya: pada pertemuan kedua, beban kajiannya berupa Hubungan antara Aqidah, Syari'ah dan Akhlak pada mata kuliah Akhlak Tasawuf. Dengan demikian, poin-poin beban kajiannya meliputi: Pengertian Aqidah, Syari'ah dan Akhlak, Perbedaan dan Persamaan Aqidah, Syari'ah dan Akhlak, dan bentuk Keterikatan antara Aqidah, Syari'ah dan Akhlak dalam ajaran Islam. RPS ini kemudian dibawa pada saat pertemuan awal dalam kontrak belajar dan pengenalan mata kuliah.

Kedua, dosen menyusun kontrak belajar mahasiswa yang di dalamnya terdapat kesepakatan-kesepakatan dan aturan main perkuliahan. Metode pembelajaran KLP diletakkan pada bagian aturan main perkuliahan, di mana isinya disusun sebagai berikut: Pertama, mahasiswa secara individu diwajibkan untuk mencari data, paling sedikit lima sumber yang berbeda dari berbagai referensi yang relevan dengan beban yang telah ditetapkan. Kedua, data yang diperoleh, harus diambil intinya dengan menyertakan sumber rujukan yang lengkap dan ditulis tangan pada kertas folio bergaris. Ketiga, hasil kerja mahasiswa tersebut harus dikumpulkan pada saat masuk kelas, sebelum perkuliahan berlangsung, sebagai “Tiket Masuk” perkuliahan.

Ketiga, dosen menyusun portofolio penilaian perkuliahan semester dalam bentuk aplikasi Excel, dengan sebaran penilaian sebagai berikut: 1) Nilai untuk catatan individu hasil penelusuran referensi diberi kode " $\mathrm{CT}$ " dengan bobot nilai $35 \%$; 2) Nilai untuk presentasi dadakan, pertanyaan, sanggahan, penambahan data, jawaban pertanyaan dan keaktifan lainnya, diberi kode " $\mathrm{P}$ " dengan bobot nilai $25 \%$; 3) Nilai Ujian Akhir Semester (UAS) diberi kode “UAS" dengan bobot nilai $20 \%$; 4) Nilai untuk Ujian Tengah Semester (UTS) diberi kode “UTS" dengan 
bobot nilai $10 \%$; 5) Nilai untuk tugas tambahan diberi kode "TGS" dengan bobot nilai 5\%; dan, 6) Nilai untuk kehadiran diberi kode "HDR" dengan bobot nilai 5\%.

Keempat, pada saat perkuliahan berlangsung, mahasiswa tertentu secara acak diminta untuk mempresentasikan hasil temuannya dari penelusuran referensinya. Mahasiswa yang lain, harus siap memberikan masukan, sanggahan, penambahan, bertanya, atau menjawab pertanyaan dari mahasiswa lainnya dalam seminar kelas. Penilaian dilakukan langsung pada saat seminar kelas, masingmasing individu mahasiswa berhak mendapatkan nilai harian, yang akan diakumulasikan pada akhir perkuliahan semester. Pada akhir perkuliahan (tengah semester dan akhir semester), mahasiswa diminta mengetik ulang catatannya yang telah diperbaiki secara berkelompok menjadi sebuah makalah.

Kelima, di akhir perkuliahan (sebelum UAS), mahasiswa diajak untuk mengkodifikasi hasil kerja (catatan yang berupa tulisan tangan mereka) secara bersama-sama, sekaligus sharing pengalaman belajar. Untuk kegiatan ini, mahasiswa harus membawa kardus bekas, kertas kado, gunting, lem, double tip, cutter, penggaris besi, dan stapler. Kegiatan ini bertujuan untuk belajar menghargai hasil kerja sendiri, agar orang lain dapat menghargai hasil kerja kita, sekaligus untuk bahan referensi ketika kelak ingin membuat artikel ilmiah. Jika memungkinkan, maka dapat dijadikan sebagai “kado" untuk kedua orang tua di rumah.

\section{Metode KLP untuk Mata Kuliah Ilmu-Ilmu Keislaman}

Pembahasan tentang keilmuan Islam sudah sejak lama dirumuskan oleh Al-Ghazali, yang membagi ilmu pengetahuan Islam menjadi dua, yaitu ilmu pokok (fardlu 'ain) dan ilmu cabang (ilmu fardlu kifayah). Ilmu yang wajib dicari secara profesional yang dimaksud oleh Al-Ghazali antara lain: Ilmu Fiqh, Ilmu Kalam dan Ilmu Tasawuf yang berhubungan dengan ibadah mahdlah. Sementara ilmu cabangnya antara lain: Ilmu fisika, Kesehatan, Kimia dan lain-lain ${ }^{16}$. Seiring perkembangan zaman, kajian keislaman juga turut berkembang sesuai kebutuhan

16 Asiyah, "Epistemologi Keilmuan Baru di Perguruan Tinggi Keagamaan Islam Negeri: Transformasi dari STAIN/IAIN Menjadi UIN", dalam MADANIA: Jurnal Kajian Keislaman, Vol. 20. No. 2, Desember 2016, hlm. 233. 
umat. Khususnya di Indonesia, berdirinya Perguruan Tinggi Agama Islam tahun 1951, munculnya ADIA (Akademi Dinas Ilmu Agama) tahun 1957 di Jakarta, yang kemudian berubah menjadi IAIN (Institut Agama Islam Negeri) di tahun 1960. Sejak tahun 2000-an, perlahan-lahan IAIN berubah bentuk menjadi Universitas Islam Negeri (UIN), di mana kajian ilmu-ilmu keislaman dikembangkan sedemikian rupa, seperti halnya perguran tinggi umum lainnya ${ }^{17}$.

Ilmu-ilmu keislaman atau Ilmu agama Islam merupakan bagian dari rumpun ilmu-ilmu budaya dan ilmu-ilmu sosial. Dalam pembidangan keilmuan secara umum, ‘Ulumul Qur'an, ‘Ulumul Hadits, Ilmu Kalam, Ilmu Ushul Fiqh, Ilmu Fiqh dan sejenisnya masuk dalam rumpun ilmu budaya (humaniora) yang bersifat ideal dan normatif. Sementara ilmu Sejarah Peradaban Islam, Ilmu Pendidikan Islam dan Ilmu Dakwah, masuk dalam rumpun ilmu-ilmu sosial yang bersifat aktual dan empiris ${ }^{18}$.

Wujud konkrit studi ilmu-ilmu dasar keislaman dimaksud dalam silabus tercakup ke dalam bidang-bidang studi tentang: al-Qur'an dan hadits, Sejarah dan Peradaban Islam, Hukum Islam dan Pranata Sosial, Ilmu Kalam-Filsafat dan Tasawuf, dan Pemikiran Modern Dalam Islam ${ }^{19}$. Harun Nasution, dalam bukunya "Klasifikasi Ilmu dan Tradisi Penelitian Islam: Sebuah Perspektif Islam"20, membagi disiplin ilmu-ilmu keislaman menjadi dua kelompok yaitu kelompok dasar dan kelompok cabang, berikut ini: Pertama, kelompok dasar, meliputi: Tafsir, Hadits, Aqidah/Ilmu Kalam, Filsafat Islam, Tasawuf, Tarekat, Perbandingan Agama, serta perkembangan modern dalam Ilmu-ilmu Tafsir, Hadits, Ilmu Kalam dan Filsafat. Kedua, Kelompok Cabang, meliputi: a) Ajaran yang mengatur masyarakat, terdiri dari Ushul Fiqh, Fikih Muamalah, Fikih Ibadah, Fikih Siyasah, Peradilan, dan Perkembangan Modern; b) Peradaban Islam, mencakup: Sejarah Islam, termasuk didalamnya sejarah politik, ekonomi, administrasi, kemiliteran, kepolisian, dan

\footnotetext{
17 Asiyah, “Epistemologi Keilmuan......, hlm. 231-232.

18 Baca: Henri Marginau dan David Bergamini, The Scientist, (New York: Time Corporated, 1964), hlm. 86-99.

19 Muhibbudin Hanafiah, "Revitalisasi Metodologi dalam Studi Islam: Suatu Pendekatan Terhadap Studi Ilmu-ilmu Keislaman", dalam Jurnal Ilmiah Didaktika, Vol. xi, No. 2, 2011, hlm. 300.

${ }^{20}$ Harun Nasution, "Klasifikasi Ilmu dan Tradisi Penelitian Islam: Sebuah Perspektif", dalam: Harun Nasution, dkk, Tradisi Baru Penelitian Agama Islam: Tinjauan Antar Disiplin Ilmu, (Bandung: t.tp, 1998), hlm. 73.
} 
lain-lain. Sejarah pemikiran Islam meliputi ilmu kalam, filsafat dan tasawuf. Sains Islam. Budaya Islam, meliputi arsitektur, kaligrafi, seni lukis, seni tari, musik, dan lain-lain. Studi kewilayahan Islam; c) Bahasa-bahasa dan sastra Islam terutama bahasa dan sastra Arab; d) Pengajaran Islam kepada anak didik, mencakup ilmu pendidikan Islam, filsafat pendidikan Islam, sejarah pendidikan Islam, lembaga pendidikan Islam, dan perkembangan modern dalam pendidikan Islam; dan, e) Penyiaran Islam, mencakup sejarah dakwah, metode dakwah, materi dakwah, perkembangan modern dalam dakwah Islam, dan lain sebagainya ${ }^{21}$.

Istilah Ilmu-ilmu keislaman, dalam konteks keilmuan secara umum dikenal dengan "Islamic sciences". Para pemikir muslim, banyak yang menggunakan istilah ini sebagai padanan katanya, seperti halnya Abdus Salam (1987), M. Omar Farooq (2003), Osman Bakar (2003), M. Hashim Kamali (2003), Alparslan Acikgenc (2003). Berdasarkan pengertian ilmu-ilmu keislaman sebagai Islamic Sciences, maka yang termasuk sebagai ilmu-ilmu keislaman adalah ilmu-ilmu agama Islam sebagaimana dikenal selama ini, seperti Tafsir, Hadits, Fiqh, Kalam, Tasawuf dan lain sebagainya yang berkaitan atau dihubungkan dengan term Islam²

Implementasi pembelajaran ilmu-ilmu keislaman tercermin dalam struktur kurikulum di masing-masing program studi Perguruan Tinggi Keagamaan Islam. Semua mata kuliah di PTKI pada dasarnya merupakan bagian dari ilmu-ilmu keislaman tersebut. Dengan berkembangnya PTKI dari Institut menjadi Universitas, maka pada dasarnya tidak ada lagi dikotomi antara ilmu umum dan ilmu-ilmu keislaman. Semuanya telah diintegrasikan menjadi suatu disiplin ilmu yang lengkap dalam perspektif Islam. Hanya saja yang dimaksud dengan ilmuilmu keislaman dalam penelitian ini, masuk pada kategori ilmu-ilmu dasar Islam yang merupakan pengembangan dari ilmu dasar yang mempelajari tentang pokok-pokok Islam. Ilmu-ilmu keislaman yang menjadi pembahasan penelitian ini

${ }^{21}$ Mastuhu dan Deden Ridwan, Tradisi Baru Penelitian Agama Islam: Tinjauan Antar Disiplin Ilmu, (Bandung: Nuansa, 1998), hlm. 7-8.

${ }^{22}$ Huzni Thayyar, "Model-model Integrasi Ilmu dan Upaya Membangun Landasan Keilmuan Islam: Survey Literatur Terhadap Pemikiran Islam Kontemporer," Naskah Makalah ACIS Diktis Kemenag, hlm. 6. 
adalah Ilmu Kalam, Akhlak Tasawuf, Metodologi Studi Islam dan Pendidikan Agama Islam ${ }^{23}$.

Pemilihan atas empat mata kuliah ini dimaksudkan untuk memudahkan dalam pengambilan sampel di lapangan. Selain itu, karena peneliti selama dua tahun terakhir juga mengajar ketiga mata kuliah tersebut dengan menggunakan metode KLP. Keempat mata kuliah tersebut merupakan mata kuliah dasar yang sangat menentukan dalam perkuliahan-perkuliahan selanjutnya, dalam rangka membentuk para sarjana yang memiliki kompetensi keilmuan Islam yang cerdas, bertaqwa dan berakhlak mulia. Ketiga mata kuliah ini membutuhkan lebih banyak atas ketiga aktifitas pembelajaran aktif, yaitu: membaca, berfikir dan menulis, jika dibandingkan dengan mata kuliah-mata kuliah lainnya.

\section{Hasil Penelitian}

Penelitian ini menggunakan metode penelitian tindakan kelas (PTK), di mana penelitian dilakukan dengan dua siklus, yaitu siklus uji coba pertama untuk melihat model pembelajaran mahasiswa yang biasa berlangsung, dan siklus kedua untuk menerapkan metode KLP. Langkah awal yang ditempuh adalah observasi pembelajaran mahasiswa di kelas dengan metode yang biasa digunakan oleh dosen yang bersangkutan. Peneliti mengikuti pembelajaran dari awal hingga akhir perkualiahan. Kemudian memberikan beberapa pertanyaan mengenai tingkat keterserapan materi yang diajarkan. Langkah kedua adalah dengan mengajak dosen-dosen yang bersangkutan untuk menggunakan metode KLP dalam pembelajaran (coaching clinic) dengan kegiatan membuat perencanaan pembelajaran. Langkah ketiga adalah meminta dosen menerapkan metode KLP, dan peneliti mengikuti pembelajaran sebagaimana di langkah pertama. Kemudian, peneliti membandingkan hasil akhir pembelajaran dari sebelum menggunakan metode KLP dengan sesudahnya.

${ }^{23}$ Ilmu Kalam, Akhlak Tasawuf dan Metodologi Studi Islam merupakan bagian dari Ilmuilmu dasar (Islamic Basic Knowledge) di Perguruan Tinggi Keagamaan Islam, berdasarkan Keputusan Direktur Jenderal Pembinaan Kelembagaan Agama Islam Departemen Agama Nomor E/52/1995 tentang Topik Inti Kurikulum Nasional Program Srata Satu (S1) Institut Agama Islam Negeri (IAIN). Muhibuddin Hanafiah, "Revitalisasi Metodologi Dalam Studi Islam: Suatu Pendekatan terhadap Studi Ilmu-ilmu Keislaman”, dalam Jurnal Ilmiah DIDAKTIKA, Vol. XI, No. 2, Februari 2011, hlm. 294. 
Berdasarkan hasil penelitian yang telah dilakukan penulis, diperoleh kesimpulan bahwa metode pembelajaran KLP terbukti dapat meningkatkan hasil belajar mahasiswa pada mata kuliah dasar ilmu-ilmu keislaman (Akhlak Tasawuf, Ilmu Kalam dan Metodologi Studi Islam), baik di IAIN Pontianak maupun di STAI Mempawah. Kesimpulan itu didasarkan pada hasil penelitian yang menyatakan bahwa:

Pertama, pelaksanaan pembelajaran dosen pada mata kuliah ilmu-ilmu Keislaman (Akhlak Tasawuf, Ilmu Kalam dan Metodologi Studi Islam) sudah berjalan sangat baik. Perhitungan ini dilakukan dalam rangka melihat sejauh mana penerapan metode KLP dilaksanakan oleh dosen dengan pedoman observasi yang telah ditentukan. Perhitungan dilakukan dengan menggunakan scoring (1-4) dengan jumlah 14 pertanyaan. Pada siklus I nilai rata-ratanya adalah 2,46 meningkat pada siklus II menjadi 3,46.

Kedua, penerapan Metode KLP dapat meningkatan hasil belajar mahasiswa, dilihat dari hasil nilai tes per siklus. Pada siklus I rata-rata kelas mata kuliah Akhlak Tasawuf berada pada angka 71,35 dimana nilai tertinggi yaitu 84 . Pada siklus II ketuntasan kelas mencapai 100\% dengan nilai rata-rata 77,4 dan nilai tertinggi yaitu 90. Pada mata kuliah Ilmu Kalam, rata-rata nilai pada siklus I adalah 74,27 dengan nilai tertinggi 90. Sementara pada siklus II meningkat ratarata menjadi 78,58 dengan nilai tertinggi 92. Sedangkan untuk mata kuliah Metodologi studi Islam pada siklus satu berada pada angka 70,33 dengan nilai tertinggi 80, dan pada siklus II, meningkat menjadi rata-rata 77,74 dengan nilai tertinggi 90.

Ketiga, ada perbedaan signifikan antara sebelum dan sesudah penggunaan metode KLP dalam pembelajaran mata kuliah dasar ilmu-ilmu keislaman (Akhlak Tasawuf, Ilmu Kalam dan Metologi Studi Islam) terhadap hasil belajar mahasiswa, di mana nilai rata-rata pada siklus I (sebelum) yaitu 71,98 dan meningkat pada siklus II (sesudah) menjadi 77,90. Selisih 5,92 point, yang menandakan adanya peningkatan signifikan atas perlakuan dengan menggunakan metode KLP dibandingkan dengan tidak menggunakan metode tersebut. 


\section{Kesimpulan}

Metode adalah sebuah metode pembelajaran yang berorientasi pada pembelajaran aktif dengan strategi seminar kelas. Metode ini terbukti berhasil meningkatkan prestasi belajar mahasiswa dari berbagai aspek kompetensi, seperti membaca, menulis dan mengekspresikan pemikiran mereka di dalam kelas. Dengan demikian, metode KLP akan sangat cocok untuk diterapkan dalam pembelajaran mata kuliah ilmu-ilmu keislaman, baik di Perguruan Tinggi Keagamaan Islam (PTKI), maupun Perguruan Tinggi Umum (PTU) yang mengajarkan mata kuliah keislaman, khususnya mata kuliah dasar, seperti: Ilmu Kalam, Akhlak Tasawuf, Metodologi Studi Islam dan Pendidikan Agama Islam.

\section{DAFTAR PUSTAKA}

Achiraeniwati, Eri, dkk., "Perancangan Ulang Kursi Kuliah yang Ergonomis di Universitas Islam Bandung Jl. Tamansari Nomor 1 Bandung", dalam Ethos: Jurnal Penelitian dan Pengabdian, Vol. 6 No. 1, Januari 2018, hlm. 162-170. (DOI: https:// doi.org/10.29313/ethos.v6i1.3572)

Aldarmono, "Identifikasi Gaya Kognitif (Cognitive Style) Peserta Didik dalam Belajar", dalam Al-Mabsut: Jurnal Studi Islam dan Sosial, Vol. 3, No. 1, 2012. (DOI: http:/ / ejournal.iaingawi.ac.id/index.php/almabsut/article/ view/39)

Asiyah, "Epistemologi Keilmuan Baru di Perguruan Tinggi Keagamaan Islam Negeri: Transformasi dari STAIN/IAIN menjadi UIN", dalam MADANIA: Jurnal Kajian Keislaman, Vol. 20. No. 2, Desember 2016.

Depdikbud, Penelitian Tindakan Kelas (Class Room Action Research), Jakarta: Dikti Proyek, 1999.

Djamaluddin, "Reorientasi Pembelajaran Akhlak Tasawuf di Perguruan Tinggi”, Tadris: Jurnal Pendidikan Islam, Vol. 3 Nomor 1 Tahun 2008. (DOI:dx.doi.org/10.19105/ jpi.v3i1.227) 
Elmansyah, Memerangi Plagiarisme di Kalangan Mahasiswa, Harian Pontianak Post, 28 Januari 2014.

, "Studi Eksperimentasi Metode KLP dalam Pembelajaran Mata Kuliah Ilmuilmu Keislaman di IAIN Pontianak dan STAI Mempawah Tahun 2017", Naskah Laporan Penelitian Kompetitif Individual, Pontianak: LP2M IAIN Pontianak, 2017.

Hanafiah, Muhibuddin, "Revitalisasi Metodologi Dalam Studi Islam: Suatu Pendekatan terhadap Studi Ilmu-ilmu Keislaman", dalam Jurnal Ilmiah DIDAKTIKA, Vol. XI, No. 2, Februari 2011, hlm. 292-302.

Marginau, Henri dan Bergamini, David, The Scientist, New York: Time Corporated, 1964.

Mastuhu dan Ridwan, Deden, Tradisi Baru Penelitian Agama Islam: Tinjauan Antar Disiplin Ilmu, Bandung: Nuansa, 1998.

Muhtadi, Ali, “Model Pembelajaran “Active Learning” dengan Metode Kelompok untuk Meningkatkan Kualitas Proses Pembelajaran di Perguruan Tinggi," Naskah Prosiding Seminar Internasional, PPs Universitas Pendidikan Bandung, 2009.

Nasution, Harun, dkk., Tradisi Baru Penelitian Agama Islam: Tinjauan antar Disiplin Ilmu, (Bandung: t.tp, 1998).

Nurhayanti, Ketut, "Penerapan Model Pembelajaran Isu Sosial-Keagamaan Berbasis Masalah Sebagai Strategi Mengajar Agama Hindu di Perguruan Tinggi", dalam Soshum: Jurnal Sosial dan Humaniora [Journal of Social Sciences and Humanities], [S.1.], Vol. 7, No. 1, September 2017, hlm. 79-89. (DOI:http://ojs.pnb.ac.id/index.php/ SOSHUM/article/view/565)

Silberman, M. L. Active Learning: 101 Strategi Pembelajaran Aktif (terjemahan), Bandung: Nuansa, 2006. 
Supriati, Endang, "Strategi Pembelajaran Berbasis Teknologi Informasi", dalam SUMETRIS: Jurnal Teknik Mesin, Elektro dan Ilmu Komputer, Vol. 2 No. 1 2013, hlm. 72-77. (DOI 10.24176/ simet.v2i1.104)

Thayyar, Huzni, “Model-model Integrasi Ilmu dan Upaya Membangun Landasan Keilmuan Islam: Survey Literatur Terhadap Pemikiran Islam Kontemporer," dalam Naskah Makalah ACIS Diktis Kemenag RI, http://diktis.kemenag.go.id/acis/ancon06/makalah/Makalah\%20Husni\%20 Thoyyar.pdf, diakses pada 24 November 2018.

Widayati, Ani, "Penelitian Tindakan Kelas", dalam Jurnal Pendidikan Akuntansi Indonesia, Vol. VI, Nomor 1, 2008, hlm. 87-93. 